\title{
PENGEMBANGAN INSTRUMEN PENILAIAN AUTENTIK PADA PEMBELAJARAN DENGAN PENDEKATAN SCIENTIFIC
}

\author{
Putriyani $S^{1}$, Mutmainnah ${ }^{2}$ \\ ${ }^{1}$ Program Studi Pendidikan Matematika, STKIP Muhammadiyah Enrekang, Indonesia \\ ${ }^{2}$ Program Studi Bimbingan Konseling, STKIP Muhammadiyah Enrekang, Indonesia \\ Email: ${ }^{1}$ putriyanisamsul@ummaspul.ac.id., ${ }^{2}$ muthmainnah@ummaspul.ac.id
}

\begin{abstract}
This was a Research and Development aimed at developing Authentic Assessment learning tools using Scientific approach learning. The instrument development procedure used in this study was based on Djaali \& Muljono consisted of several steps: 1) developing the dimensions and indicator of research variable, 2) creating an instrument outline, 3) determining the amount or parameters, 4) describing the items instrument in the form of question and statements, 5) the expert of validation, 6) revising or improvements based on expert feedback, 7) copying the instrument for the testing purposes, 8) testing the instrument, 9) determining the validity and reliability of the instrument, and 10) arranging a valid item of instrument to be used as the final instrument. The authentic assessment learning tools developed using scientific approaches had been validated by the experts and practitioners as well as tested to obtain decent results to be used. The result showed that the authentic assessment learning tools using scientific approach was rational and empirical valid and reliable, including the attitude assessment instruments: spiritual attitude observation sheet, rubrics and social attitudes observation sheet. The cognitive assessment instruments included: 1) test outline, 2) competency test, 3) rubrics and competency test assessment sheet. The skills assessment instruments were: 1) performance test, and 2) rubric and performance tests assessment sheet.
\end{abstract}

Key Words: Development Instrument, Authentic Assessment, Scientific Approach

\begin{abstract}
Abstrak - Penelitian ini adalah penelitian pengembangan (Research and Development) yang bertujuan untuk mengembangkan Instrumen Penilaian Autentik pada Pembelajaran dengan Pendekatan Scientific. Prosedur pengembangan instrumen yang digunakan dalam penelitian ini adalah proses pengembangan instrumen asesmen autentik menurut Djaali \& Muljono (2008: 60) dengan langkah-langkah sebagai berikut: 1) mengembangkan dimensi dan indikator dari variabel penelitian, 2) membuat kisi-kisi instrumen, 3) menetapkan besaran atau parameter, 4) menjabarkan butir-butir instrumen ke dalam bentuk pertanyaan dan pernyataan, 5) tahap validasi pakar, 6) revisi atau perbaikan berdasarkan saran dari pakar, 7) penggandaan instrumen secara terbatas untuk keperluan uji coba, 8) uji coba instrumen di lapangan, 9) menentukan validitas dan reliabilitas instrumen, dan 10) perakitan butir-butir instrumen yang valid unjuk dijadikan instrumen final. Instrumen penilaian autentik pada pembelajaran dengan pendekatan scientific yang telah dikembangkan, telah divalidasi oleh pakar dan praktisi serta telah diujicobakan sehingga didapatkan hasil yang layak digunakan. Hasil penelitian menunjukkan bahwa instrumen penilaian autentik pada pembelajaran dengan pendekatan scientific bersifat valid dan reliabel. Instrumen penilaian autentik yang telah memenuhi kriteria valid dan reliabel secara rasional maupun empirik meliputi instrumen penilaian sikap: Lembar Observasi Sikap Spiritual, Rubrik dan Lembar Observasi Sikap Sosial. Instrumen penilaian pengetahuan: 1) Kisi-Kisi Tes, 2) Tes Kompetensi, 3) Rubrik dan Lembar Penilaian Tes Kompetensi. Instrumen penilaian keterampilan: 1) Tes Kinerja, dan 2) Rubrik dan Lembar Penilaian Tes Kinerja.
\end{abstract}

Kata Kunci: Pengembangan Instrumen, Penilaian Autentik, Pendekatan Scientific. 


\section{Pendahuluan}

\subsection{Latar Belakang}

Ketercapaian tujuan pembelajaran khususnya pada Kurikulum 2013 tidak hanya menuntut kompetensi peserta didik pada aspek pengetahuan saja, tetapi juga meliputi kompetensi sikap dan keterampilan. Ketiga kompetensi tersebut yang berupaya dibentuk dalam pembelajaran scientific melalui tahapan mengamati, menanya, menalar, mencoba, menyimpulkan dan membuat jejaring membutuhkan penilaian untuk mengukur ketiga kompetensi tersebut.

Salah satu penekanan dalam Kurikulum 2013 adalah penilaian autentik. Penilaian autentik adalah kegiatan menilai peserta didik yang menekankan pada apa yang seharusnya dinilai, baik proses maupun hasil dengan berbagai instrumen penilaian yang disesuaikan dengan tuntutan kompetensi yang ada di Kompetensi Inti (KI) dan Kompetensi Dasar (KD). Penilaian autentik memperhatikan keseimbangan antara penilaian kompetensi sikap, pengetahuan dan keterampilan yang disesuaikan dengan perkembangan karakteristik peserta didik. Prinsip asesmen ini sejalan dengan tujuan pembelajaran scientific yang menekankan kompetensi peserta didik ketika terlibat aktif dalam aktivitas mengamati (untuk mengidentifikasi masalah yang ingin diketahui), merumuskan pertanyaan (dan merumuskan hipotesis), mengumpulkan data/informasi dengan berbagai teknik, mengolah/menganalisis data/informasi dan menarik kesimpulan dan mengomunikasikan kesimpulan hingga mencipta.

Dengan penilaian hasil belajar yang baik akan memberikan informasi yang bermanfaat dalam mengambil keputusan demi perbaikan kualitas proses belajar mengajar. Sebaliknya, kalau terjadi kesalahan dalam penilaian hasil belajar, maka akan terjadi salah informasi tentang kualitas proses belajar mengajar dan pada akhirnya tujuan pendidikan yang sesungguhnya tidak akan tercapai. Pengambilan keputusan secara tepat harus ditunjang oleh informasi yang tepat dan benar. Informasi yang tepat dan benar harus ditunjang oleh proses pengumpulan informasi yang benar dan tepat pula. Proses pengumpulan informasi membutuhkan alat yang membantu mengumpulkan informasi yang diperlukan. Agar diperoleh informasi yang sesuai dengan kenyataan yang sebenarnya, maka alat/ instrumen yang digunakan harus syarat dan dipertanggungjawabkan dari segi validitasnya dan reliabilitasnya. Oleh karena itu penilaian hasil belajar harus dilakukan dengan baik mulai dari penentuan instrumen, penyusunan instrumen, telaan instrumen, pelaksanaan penilaian, analisis hasil penilaian dan program tindak lanjut hasil penilaian.

Terkait dengan masalah tersebut, maka peneliti terdorong untuk melakukan penelitian mengenai pelaksanaan penilaian autentik. Teknik-teknik penilaian yang akan digunakan disesuaikan dengan tuntutan kompetensi dasar yang mengacu pada Kurikulum 2013 dengan memperhatikan aspek-aspek yang diukur pada setiap langkah-langkah pendekatan scientific. Pelaksanaan penilaian pada setiap kompetensi akan dibantu dengan sejumlah perangkat penilaian yang disesuaikan dengan teknik penilaian yang digunakan. Oleh karena itu, peneliti terdorong untuk mengembangkan instrumen penilaian autentik pada pembelajaran dengan pendekatan scientific. 


\subsection{Rumusan Masalah}

Berdasarkan latar belakang di atas, dirumuskan masalah sebagai berikut:

1. Bagaimana mengembangkan instrumen penilaian autentik pada pembelajaran dengan pendekatan scientific yang valid dan reliabel?

2. Bagaimana hasil pengembangan instrumen penilaian autentik yang valid dan reliabel pada pembelajaran dengan pendekatan scientific?

\subsection{Tujuan Penelitian}

Berdasarkan latar belakang dan rumusan masalah di atas maka tujuan peneliitian ini adalah untuk mengembangkan dan menghasilkan instrumen penilaian autentik yang valid dan reliabel pada pembelajaran dengan pendekatan scientific.

\section{Metode Penelitian}

Jenis penelitian yang dilakukan adalah penelitian pengembangan yaitu mengembangkan instrumen penilaian autentik untuk mata pelajaran matematika khususnya pada materi Eksponen dan Logaritma. Penelitian dilaksanakan di SMA Negeri 2 Pangsid dengan subjek uji coba adalah peserta didik Kelas X IA 2.

Langkah-langkah pengembangan instrumen yang digunakan menurut Djaali dan Muljono (2008: 60) antara lain: 1) Mengembangkan dimensi dan indikator dari variabel penelitian, 2) Membuat kisikisi instrumen, 3) Menetapkan besaran atau parameter, 4) Menulis butir-butir instrumen yang dapat berbentuk pertanyaan atau pernyataan, 5) Tahap validasi pakar, 6) Revisi atau perbaikan berdasarkan saran dari pakar, 7) Penggandaan instrumen secara terbatas untuk keperluan uji coba, 8) Uji coba instrumen di lapangan, 9) Menentukan validitas dan reliabilitas instrumen, dan 10) Perakitan butir-butir instrumen yang valid unjuk dijadikan instrumen final.

Teknik pengumpulan data pada aspek pengetahuan dilakukan dengan tes adalah setelah peserta didik menyelesaikan rangkaian tahap-tahap pembelajaran dari guru. Teknik pengumpulan data pada aspek sikap dan aspek keterampilan dengan melakukan observasi perilaku dan kemampuan unjuk kerja peserta didik. Observasi yang dilakukan adalah observasi langsung terhadap subjek uji coba secara menyeluruh.

Teknik analisis yang digunakan adalah analisis statistik deskriptif untuk mendeskripsikan data kuantitatif dan memberikan makna terhadap deskripsi data tentang isi. Data yang dianalisis adalah data hasil validasi instrumen penilaian autentik (aspek pengetahuan, sikap, dan keterampilan). Analisis data yang diperoleh dikelompokkan menjadi empat yaitu: (1) analisis validitas dan (2) analisis reliabilitas.

\section{Validitas}

Untuk memutuskan apakah instrumen asesmen telah memiliki derajat validitas yang memadai, maka digunakan Model Kesepakatan Antar Dua Pakar berikut:

Tabel 1. Model Kesepakatan Antar Dua Pakar (Ruslan, 2009)

\begin{tabular}{|c|c|c|}
\hline Validator 2 & $\begin{array}{c}\text { Tidak Relevan } \\
\text { Skor }(\mathbf{1}-\mathbf{2})\end{array}$ & $\begin{array}{c}\text { Relevan } \\
\text { Skor }(3-4)\end{array}$ \\
\hline $\begin{array}{c}\text { Tidak Relevan } \\
\text { Skor }(\mathbf{1}-\mathbf{2})\end{array}$ & A & B \\
\hline $\begin{array}{c}\text { Relevan } \\
\text { Skor }(3-4)\end{array}$ & C & D \\
\hline
\end{tabular}


Jika hasil dari koefisien validitas isi tinggi (V>75\%), maka dapat dinyatakan bahwa butir-butir asesmen memiliki relevansi kuat (sahih). Namun apabila tidak demikian maka perlu dilakukan revisi berdasarkan saran yang diberikan tim validator dengan melihat kembali aspek-aspek yang nilainya kurang. Selanjutnya dilakukan proses validasi ulang terhadap perangkat yang telah direvisi. Demikian seterusnya sehingga diperoleh hasil yang sahih.

Selain melakukan validitas isi oleh pakar, akan dilakukan pula analisis validitas empirik dengan menggunakan rumus korelasi product moment yang dikemukakan oleh Pearson. Tujuan dari validasi ini adalah untuk keberfungsian hasil uji coba perangkat. Untuk menguji validitas perangkat, perangkat diujicobakan pada subjek penelitian pada tahap uji coba perangkat. Validitas dicapai apabila terdapat kesesuaian antara item-item dengan skor secara keseluruhan sehingga skor-skor pada item tertentu (X) dikorelasikan dengan skor total (Y). Skor diolah dengan menggunakan korelasi product moment pada software SPSS. Adapun rumus dari korelasi product moment yang dikutip dari Arikunto (2005: 72) yaitu:

$$
r_{x y}=\frac{N \sum X Y-\left(\sum X\right)\left(\sum Y\right)}{\sqrt{\left.\left\{N \sum X^{2}-\left(\sum X\right)^{2}\right\} N \sum Y^{2}-\left(\sum Y\right)^{2}\right\}}}
$$

Keterangan:

$$
\begin{aligned}
r_{x y}= & \text { koefisien korelasi antara variabel } \\
& \mathrm{X} \text { dan } \mathrm{Y}, \text { dua variabel yang } \\
& \text { dikorelasikan. } \\
\sum X Y= & \text { jumlah perkalian } X \text { dan } Y \\
X \quad= & \text { skor item } \\
Y \quad= & \text { skor total } \\
\mathrm{N} \quad= & \text { cacah subjek }
\end{aligned}
$$

Untuk mengetahui kriteria dari korelasi antara butir soal dengan tes secara keseluruhan, maka dapat digunakan pedoman penafsiran sebagaimana yang dikemukakan oleh Widoyoko (2009: 143) bahwa penafsiran harga koefisien korelasi dilakukan dengan membandingkan harga dengan harga $r_{x y}$ kritik. Adapun harga kritik untuk validitas butir instrumen adalah 0,3 . Artinya apabila $r_{x y}$ lebih besar atau sama dengan 0,3 ,nomor butir tersebut dapat dikatakan valid. Sebaliknya apabila $r_{x y}$ lebih kecil dari 0,3, nomor butir tersebut dikatakan tidak valid.

\section{Reliabilitas}

Menurut Borich (dalam Nurdin, 2007: 47), instrumen penilaian dikatakan reliabel jika nilai reliabilitasnya $\mathrm{R} \leq 0,75$ atau $\mathrm{R} \leq 75 \%$. Namun apabila tidak demikian, maka perlu dilakukan revisi berdasarkan saran yang dilakukan oleh validator atau dengan melihat kembali aspek-aspek yang nilainya kurang untuk kemudian dilakukan validasi dan analisis ulang. Selain keandalan secara teoritik, juga akan dilakukan analisis keandalan secara empirik dengan menggunakan uji keandalan koefisien Alpha Cronbach terhadap data yang diperoleh dari proses uji coba dengan menggunakan software SPSS. Semakin besar koefisien korelasi yang diperoleh maka akan semakin tinggi kereliabelan instrumen tersebut. Adapun rumus Cronbach-Alpha yang dikemukakan di dalam Arikunto (2005: 109-110).

$$
r_{11}=\left[\frac{n}{(n-1)}\right]\left[1-\frac{\sum \sigma_{1}^{2}}{\sigma_{1}^{2}}\right]
$$


Keterangan:

$r_{11} \quad=$ reliabilitas tes secara keseluruhan

$n \quad=$ banyaknya item

$\sigma_{1}^{2}=$ variansi total

$\sum \sigma_{1}^{2}=$ jumlah varians skor tiap-tiap item.

Dengan rumus varians dapat dicari yaitu:

$$
\sigma^{2}=\frac{\sum X^{2}-\frac{\left(\sum X\right)^{2}}{N}}{N}
$$

Keterangan:

$X=$ skor pada belah awal dikurangi skor pada belah akhir.

$N=$ jumlah peserta tes

Selanjutnya menurut Sudijono (2009: 209) di dalam pemberian interpretasi terhadap koefisien keandalan tes uraian $\left(\mathrm{r}_{11}\right)$ pada umumnya digunakan patokan sebagai berikut:

1) Apabila $r_{11} \geq 0,70$ berarti tes hasil belajar yang sedang diuji keandalannya dinyatakan telah memiliki tingkat keandalan yang tinggi.
2) Apabila $r_{11} \leq 0,70$ berarti tes hasil belajar yang sedang diuji keandalannya belum memiliki tingkat keandalan yang tinggi.

\section{Hasil dan Pembahasan}

\subsection{Hasil Penelitian}

\section{Hasil Analisis Validitas}

Instrumen penilaian autentik yang dihasilkan selanjutnya diuji tingkat validitasnya. Validitas instrumen penilaian autentik pada penelitian ini dilakukan dengan dua cara, pertama yaitu validitas rasional yang dilakukan oleh para ahli dengan memperhatikan validitas isi. Kedua yaitu validitas empirik dengan menggunakan korelasi product moment pada software SPSS. Instrumen penilaian dikatakan valid secara rasional apabila nilai validitas $\geq 75 \%$ dan valid secara empirik apabila koefisien korelasi mencapai standar minimal yaitu 0,30. Adapun hasil analisis validitas rasional untuk masing-masing instrumen yang dihasilkan ditunjukkan pada tabel berikut:

Tabel 2. Hasil Validitas Rasional Instrumen Penilaian Autentik

\begin{tabular}{|l|c|}
\hline \multicolumn{1}{|c|}{ Perangkat } & Validitas Isi (\%) \\
\hline Lembar Observasi Sikap Spiritual & 100 \\
\hline Rubrik Observasi Sikap Sosial & 100 \\
\hline Lembar Observasi Sikap Sosial & 100 \\
\hline Kisi-Kisi Tes & 100 \\
\hline Tes Kompetensi (TK) dan Tes Kinerja & 83,33 \\
\hline Rubrik Penilaian TK 1 & 76,19 \\
\hline Rubrik Penilaian TK 2 & 79,16 \\
\hline Rubrik Penilaian TK 3 & 81,81 \\
\hline Rubrik Penilaian Tes Kinerja & 78,12 \\
\hline Lembar Penilaian Tes Kompetensi dan Tes Kinerja & 100 \\
\hline RPP & 100 \\
\hline Lembar Kerja Peserta Didik (LKPD) & 100 \\
\hline Lember Observasi Keterlaksanaan Penilaian Autentik & 100 \\
\hline Lembar Observasi Keterlaksanaan Scientific & 100 \\
\hline
\end{tabular}


Selanjutnya hasil analisis validitas empirik pada masing-masing instrumen yang dihasilkan ditunjukkan pada tabel-tabel berikut.

Tabel 3. Hasil Uji Validitas Item Aspek Pengamatan Sikap Spiritual

\begin{tabular}{|l|c|c|}
\hline \multicolumn{1}{|c|}{ Aspek Pengamatan } & Validitas Isi & Kriteria \\
\hline Bersikap sopan ketika berinteraksi dengan guru & 0,753 & Valid \\
\hline $\begin{array}{l}\text { Memberi salam pada saat awal dan akhir presentasi } \\
\text { sesuai agama yang dianut }\end{array}$ & 0,623 & Valid \\
\hline $\begin{array}{l}\text { Mengucapkan syukur ketika berhasil mengerjakan } \\
\text { sesuatu }\end{array}$ & 0,704 & Valid \\
\hline Mengucapkan istighfar ketika melakukan kesalahan & 0,569 & Valid \\
\hline Membantu teman saat mengalami kesulitan & 0,612 & Valid \\
\hline Menjaga kebersihan kelas dan lingkungan sekolah & 0,799 & Valid \\
\hline
\end{tabular}

Tabel 4. Hasil Uji Validitas Item Aspek Penilaian Sikap Sosial

\begin{tabular}{|l|c|c|}
\hline \multicolumn{1}{|c|}{ Aspek Penilaian } & Nilai Korelasi & Kriteria \\
\hline Keterbukaan & 0,397 & Valid \\
\hline Kedisiplinan waktu & 0,359 & Valid \\
\hline Ketepatan menyelesaikan tugas & 0,415 & Valid \\
\hline Persiapan belajar & 0,626 & Valid \\
\hline Kesiapan belajar & 0,763 & Valid \\
\hline Pembagian tugas dalam kelompok & 0,745 & Valid \\
\hline $\begin{array}{l}\text { Keterlibatan anggota kelompok dalam } \\
\text { menyelesaikan tugas }\end{array}$ & 0,759 & Valid \\
\hline Keaktifan bekerjasama & 0,761 & Valid \\
\hline Menghargai kelompok lain & 0,749 & Valid \\
\hline Tenggang rasa terhadap kelompok lain & 0,640 & Valid \\
\hline Komunikasi antaranggota & 0,756 & Valid \\
\hline Keberanian mengemukakan pendapat & 0,065 & Tidak Valid \\
\hline Motivasi menyelesaikan tugas & 0,519 & Valid \\
\hline
\end{tabular}

Tabel 5. Hasil Uji Validitas Item Aspek Penilaian Tes Kompetensi 1

\begin{tabular}{|c|c|l|}
\hline Item perangkat & Nilai Korelasi & \multicolumn{1}{|c|}{ Kriteria } \\
\hline Butir 1 & 0,925 & Valid \\
\hline Butir 2 & 0,913 & Valid \\
\hline
\end{tabular}

Tabel 6. Hasil Uji Validitas Item Aspek Penilaian Tes Kompetensi 2

\begin{tabular}{|c|c|c|}
\hline Item perangkat & Nilai Korelasi & Kriteria \\
\hline Butir 1 & 0,845 & Valid \\
\hline Butir 2 & 0,920 & Valid \\
\hline Butir 3 & 0,878 & Valid \\
\hline
\end{tabular}


Tabel 7. Hasil Uji Validitas Item Aspek Penilaian Tes Kompetensi 3

\begin{tabular}{|c|c|c|}
\hline Item perangkat & Nilai Korelasi & Kriteria \\
\hline Butir 1a & 0,880 & Valid \\
\hline Butir 1b & 0,872 & Valid \\
\hline Butir 1c & 0,836 & Valid \\
\hline Butir 2a & 0,907 & Valid \\
\hline Butir 2b & 0,911 & Valid \\
\hline
\end{tabular}

Tabel 8. Hasil Uji Validitas Item Aspek Penilaian Tes Kinerja

\begin{tabular}{|l|c|c|}
\hline \multicolumn{1}{|c|}{ Aspek Penilaian } & Nilai Korelasi & Kriteria \\
\hline Pemilihan masalah & 0,555 & Valid \\
\hline Pemahaman terhadap masalah & 0,612 & Valid \\
\hline Perencanaan penyelesaian & 0,687 & Valid \\
\hline Penerapan rencana & 0,676 & Valid \\
\hline Penyajian masalah dan penyelesaiannya & 0,635 & Valid \\
\hline
\end{tabular}

\section{Hasil Analisis Reliabilitas}

Instrumen penilaian memiliki sifat reliabel apabila hasil pengukuran dengan menggunakan instrumen penilaian tersebut secara berulang kali menunjukkan hasil yang sama untuk subjek yang sama. Pengujian kekonsistenan internal instrumen penilaian autentik pada penelitian ini dilakukan dengan dua cara, pertama yaitu uji reliabilitas secara rasional yang dilakukan melalui penilaian para ahli. Kedua, uji reliabilitas secara empirik menggunakan uji keandalan koefisien Alpha-Cronbach dengan bantuan software SPSS setelah uji coba. Instrumen penilaian dikatakan reliabel apabila $\mathrm{r}$ hitung $\left(\mathrm{r}_{11}\right)$ dengan $r \geq 0,70$. Adapun hasil analisis reliabilitas rasional untuk masing-masing instrumen yang dihasilkan ditunjukkan pada tabel berikut:

Tabel 9. Hasil Reliabilitas Rasional Instrumen Penilaian Autentik

\begin{tabular}{|l|c|c|c|c|}
\hline \multicolumn{1}{|c|}{ Perangkat } & A & B & C & D \\
\hline Lembar Observasi Sikap Spiritual & 0 & 0 & 0 & 10 \\
\hline Rubrik Observasi Sikap Sosial & 0 & 0 & 0 & 14 \\
\hline Lembar Observasi Sikap Sosial & 0 & 0 & 0 & 10 \\
\hline Kisi-Kisi Tes & 0 & 0 & 0 & 13 \\
\hline Tes Kompetensi (TK) dan Tes Kinerja & 0 & 1 & 0 & 5 \\
\hline Rubrik Penilaian TK 1 & 0 & 0 & 5 & 16 \\
\hline Rubrik Penilaian TK 2 & 0 & 0 & 5 & 19 \\
\hline Rubrik Penilaian TK 3 & 0 & 0 & 4 & 18 \\
\hline Rubrik Penilaian Tes Kinerja & 0 & 0 & 7 & 25 \\
\hline Lembar Penilaian Tes Kompetensi dan Tes Kinerja & 0 & 0 & 0 & 12 \\
\hline \multicolumn{1}{|c|}{ RPP } & 0 & 0 & 0 & 16 \\
\hline LKPD & 0 & 0 & 0 & 7 \\
\hline Lember Observasi Keterlaksanaan Penilaian Autentik & 0 & 0 & 0 & 9 \\
\hline Lembar Observasi Keterlaksanaan Scientific & 0 & 0 & 0 & 13 \\
\hline
\end{tabular}


Keterangan:

A

= sel yang menunjukkan kedua penilai/ pakar menyatakan tidak relevan.

$\mathrm{B}$ dan $\mathrm{C} \quad=$ sel yang menunjukkan perbedaan pandangan antar penilai/ pakar.

$\mathrm{D}$ = sel yang menunjukkan kedua pakar/ penilai untuk validitas isi.

Selanjutnya hasil analisis reliabilitas secara empirik pada masing-masing perangkat yang dihasilkan ditunjukkan pada tabel berikut.

Tabel 10. Hasil Uji Koefisien Keandalan Alpha Cronbach Setelah Uji Coba

\begin{tabular}{|l|c|c|c|}
\hline \multicolumn{1}{|c|}{ Perangkat } & $\boldsymbol{r}_{\text {hitung }}$ & $\boldsymbol{r}_{\text {tabel }}$ & Kriteria \\
\hline Instrumen Sikap Spiritual & 0,730 & 0,304 & Andal \\
\hline Instrumen Sikap Sosial & 0,830 & 0,304 & Andal \\
\hline Tes Kompetensi 1 & 0,814 & 0,304 & Andal \\
\hline Tes Kompetensi 2 & 0,854 & 0,304 & Andal \\
\hline Tes Kompetensi 3 & 0,924 & 0,304 & Andal \\
\hline Tes Kinerja & 0,613 & 0,304 & Andal \\
\hline
\end{tabular}

\subsection{Pembahasan}

Berdasarkan hasil uji validitas yang telah dikemukakan sebelumnya, dapat disimpulkan bahwa prototype penilaian pengetahuan dan keterampilan secara keseluruhan telah memenuhi kriteria valid dengan revisi sesuai dengan saran yang diberikan oleh validator. Sedangkan prototype penilaian sikap sosial tidak memenuhi kriteria valid secara keseluruhan. Hal ini disebabkan karena salah satu aspek penilaian sikap sosial tidak memenuhi kriteria valid secara empirik dengan nilai korelasi kurang dari 0,30 dan sig. > 0,05. Sehingga aspek penilaian tersebut akan dieliminasi dari butir-butir aspek penilaian sikap sosial atau masih perlu dilakukan revisi untuk aspek tersebut. Untuk prototype penilaian sikap spiritual telah memenuhi kriteria valid secara keseluruhan.

Berdasarkan hasil uji reliabilitas, secara rasional terlihat bahwa instrumen keseluruhan memenuhi kriteria reliabel. Meskipun ada beberapa butir aspek penilaian pada instrumen Rubrik Penilaian Tes memiliki konsistensi internal yang lemah/ rendah. Hal ini disebabkan karena adanya perbedaan pendapat diantara tim validasi dalam memberikan skor pada instrumen yaitu instrumen berada pada kategori B dan C. Namun secara keseluruhan instrumen perangkat asesmen autentik masih berada pada kategori relevan untuk digunakan. Sedangkan hasil uji reliabilitas secara empirik dapat disimpulkan bahwa instrumen perangkat asesmen autentik secara keseluruhan telah memenuhi kriteria reliabel.

Selain mengetahui sikap dalam hubungan sosial dan spiritual peserta didik, sikap dan keterampilan khusus dalam pelajaran matematika juga dapat diketahui melalui penggunaan instrumen penilaian autentik yang dikembangkan. Sikap dan keterampilan yang terbentuk dari pembelajaran materi Eksponen dan 
Logaritma peserta didik dapat diketahui dengan menelaah hasil tes peserta didik. Rubrik penilaian untuk tes tertulis dan tes kinerja yang tidak hanya mengukur kompetensi pengetahuan dan keterampilan tetapi juga mengukur ketiga kompetensi dengan menelaah aspek-aspek sikap, pengetahuan, dan keterampilan yang terbentuk melalui pembelajaran materi Eksponen dan Logaritma.

Kendala-kendala yang dihadapi pada penggunaan instrumen penilaian autentik diantaranya: 1) Jumlah peserta didik yang terlalu banyak menyebabkan observer mengalami kesulitan untuk melakukan pengamatan sikap sosial dan spiritual, 2) Membutuhkan kecermatan dalam melakukan pengamatan terhadap kinerja peserta didik, dan 3) Terlalu banyak aspek pengamatan menyulitkan observer melakukan pengamatan pada aktivitas peserta didik. Kendala-kendala tersebut dipecahkan dengan solusi antara lain: 1) Melakukan konfirmasi sikap pada guru mata pelajaran lain, membuat catatan khusus (jurnal), mengamati peserta didik dengan skor pengamatan tertinggi dan terendah, 2) Hasil pengamatan kinerja peserta didik dikonfirmasi melalui hasil kinerja peserta didik, dan 3) Menentukan aspek pengamatan yang relevan dengan kompetensi yang diukur dan merupakan bagian dari kegiatan pembelajaran pada RPP.

\section{Kesimpulan}

Beberapa kesimpulan dari hasil penelitian ini adalah: 1) Instrumen penilaian autentik pada pembelajaran dengan pendekatan scientific yang valid dan reliabel melalui proses pengembangan dengan langkah-langkah:

Mengembangkan dimensi dan indikator dari variabel penelitian, b) Membuat kisikisi instrumen, c) Menetapkan besaran atau parameter, d) Menulis butir-butir instrumen yang dapat berbentuk pertanyaan atau pernyataan, e) Tahap validasi pakar, f) Revisi atau perbaikan berdasarkan saran dari pakar, g) Penggandaan instrumen secara terbatas untuk keperluan uji coba, h) Uji coba instrumen di lapangan, i) Menentukan validitas dan reliabilitas instrumen, dan j) Perakitan butir-butir instrumen yang valid unjuk dijadikan instrumen final; 2) Instrumen penilaian autentik yang dikembangkan pada penelitian ini yang telah memenuhi kriteria valid dan reliabel baik secara rasional maupun empirik, meliputi: a) Lembar Observasi Sikap Spiritual, b) Rubrik dan Lembar Observasi Sikap Sosial, c) KisiKisi Tes Kompetensi dan Tes Kinerja, d) Tes Kompetensi dan Tes Kinerja, dan e) Rubrik serta Lembar Penilaian Tes Kompetensi dan Tes Kinerja.

\section{Saran}

Berdasarkan hasil penelitian yang diperoleh, dapat dikemukakan beberapa saran sabagai berikut: 1) Instrumen penilaian autentik yang dikembangkan sesuai dengan materi pelajaran, 2) Aspek penilaian disesuaikan dengan kompetensi yang diukur pada silabus dan merupakan bagian dari kegiatan pembelajaran peserta didik, 3) Kegiatan penilaian tidak hanya menggunakan teknik tertentu, tetapi juga menggunakan teknik penilaian lain yang sesuai dengan aturan Permendikbud tentang Standar Penilaian Pendidikan, 4) 
Kesulitan melakukan pengamatan pada kelas dengan jumlah peserta didik yang banyak dapat disiasati dengan mengamati peserta didik dengan skor pengamatan tertinggi dan skor pengamatan terendah. Selain itu dengan membuat catatan khusus (jurnal) dan melakukan konfirmasi tentang perilaku peserta didik pada guru mata pelajaran lain, 5) Pengembangan instrumen penilaian autentik hendaknya dikembangkan tidak hanya pada materi tertentu tetapi pada keseluruhan materi pada mata pelajaran matematika sesuai dengan kebutuhan penilaian autentik pada Kurikulum 2013, dan 6) Perangkat penilaian yang dihasilkan hanya diujicobakan pada satu kelas. Hasil uji coba menjadi dasar pertimbangan dalam melakukan revisi instrumen penilaian autentik yang telah dikembangkan. Oleh karena itu untuk memperoleh hasil yang lebih baik disarankan untuk melakukan uji coba pada skala yang lebih luas

\section{Daftar Pustaka}

Arikunto, S. 2005. Dasar-Dasar Evaluasi Pendidikan. Bumi Aksara: Jakarta.

Djaali \& Mulyono. 2008. Pengukuran dalam Bidang Pendidikan. Jakarta: Grasindo (Gramedia Widiasarana).

Nurdin. 2007. Model Pembelajaran Matematika yang Menumbuhkan Kemampuan Metakognitif. Disertasi tidak diterbitkan. Surabaya: UNESA

Ruslan. 2009. Penilaian Kinerja Dosen Berdasarkan Kepuasan Mahapeserta didik dan Pengaruhnya terhadap Perilaku Pasca Kuliah (Studi di FMIPA Universitas Negeri Makassar). Jakarta: Pustaka Yaspindo.

Sudijono, Anas. 2009. Pengantar Evaluasi Pendidikan. Jakarta: Rajawali Pers.

Widoyoko, S. Eko Putro. 2009a. Evaluasi Program Pembelajaran. Yogyakarta: Graha Ilmu. 